\title{
SUSTAINABLE COMPENSATION AND PERFORMANCE: AN EMPIRICAL ANALYSIS OF EUROPEAN BANKS
}

\author{
ELISABETTA D'APOLITO*», ANTONIA P. IANNUZZI ${ }^{\dagger,}$, \\ STEFANIA SYLOS LABINI*,\| and EDGARDO SICA ${ }^{*}, * *$ \\ *Department of Economics, University of Foggia, Italy \\ ${ }^{\dagger}$ Department of Economics \\ Management and Business Law \\ University of Bari, Italy \\ ${ }^{\star}$ Department of Communication and Social Research (CORIS) \\ 'La Sapienza', University of Rome, Italy \\ §elisabetta.dapolito@unifg.it \\ `antoniapatrizia.iannuzzi@uniba.it \\ "stefania.syloslabini@unifg.it \\ **edgardo.sica@unifg.it
}

Received 28 July 2018

Accepted 5 March 2019

Published 9 May 2019

\begin{abstract}
This study investigates the financial and non-financial impacts of the use of sustainability criteria in banks' executive compensation plans. The sample covers all the globally and systemically important European banks over the period 2013-2017. Panel data-fixed effect estimations are employed to mitigate endogeneity concerns and to control for within-firm dynamics. The implementation of sustainable criteria in the banks' remuneration contracts was found to (i) negatively impact economic performance, (ii) negatively impact the riskiness profile, and (iii) positively impact sustainability performance. These findings have important implications for investors as well as banks. Indeed, these results are encouraging for the use of sustainability targets in executive compensation for restricting excessive risk-taking behaviors and improving sustainability performance.
\end{abstract}

Keywords: Banking compensation; sustainability targets; corporate governance; content analysis; riskiness; performance.

\section{Introduction}

In the last few years, traditional financial performance measures linked to executive compensation have been strongly criticized for encouraging excessive risk-taking,

§Corresponding author.

This is an Open Access article published by World Scientific Publishing Company. It is distributed under the terms of the Creative Commons Attribution 4.0 (CC-BY) License. Further distribution of this work is permitted, provided the original work is properly cited. 
irresponsible behavior and, ultimately, for reflecting governance failure (Kolk \& Perego 2014). For these reasons, many regulatory initiatives have emphasized the importance of including specific non-financial (or sustainability) measures in the design of compensation contracts to orient the managers' behavior towards longterm and social goals (HLEG 2018). "A compensation system - indeed - has to promote ethical behaviour and compliance with laws, regulations, and internal conduct standards" (FSB 2018, p. 6). Some examples of non-financial performance metrics are the following: customer satisfaction, compliance with internal or external rules, corporate social responsibility, diversity, employee wellbeing, stakeholder engagement, and environmental performance.

Including sustainability metrics in remuneration plans could lead to several benefits and positive implications. Primarily, these metrics allow the refocusing of managerial actions to a long-term strategy (Ittner et al. 1997, Banker et al. 2000) that could improve both the firms' financial (Banker et al. 2000, Said et al. 2003, HassabElnaby et al. 2005) and non-financial performance (Flammer et al. 2016, Velte 2016). Moreover, sustainability criteria are more able to reduce the risk-taking by firms (Lee et al. 2017) and to neutralize the misconduct risk (FSB 2017a) and any unethical behavior, including earnings manipulation (HassabElnaby et al. 2010) and discretionary accruals (Ibrahim \& C. Lloyd 2011): sustainability criteria are beneficial because they allow the strengthening of the overall performance risk adjustment process by introducing " a different lens through which performance is measured" (BCBS 2011, p. 18). Finally, the benefits gained by using sustainability criteria in remuneration contracts could be achieved at a relatively low cost. For these reasons, several firms, including banks and insurance companies (Abdelmotaal \& Abdel-Kader 2016), have recently started to include more nonfinancial performance measures in their compensation plans (Flammer et al. 2016).

Nevertheless, the extant literature on this topic is currently limited. Studies have largely focused on the US context, the pre-crisis time window and non-financial firms (Abdelmotaal \& Abdel-Kader 2016, Velte 2016, Maas 2018). To fill these gaps, this paper aims to go deeper, focusing on the banking sector and analyzing the relationships between the adoption of sustainability criteria in remuneration contracts and financial and non-financial performance. The analysis focuses on 42 European systemically important banks and is based on a five-year panel dataset (from 2013 to 2017). The main findings partially support the research hypotheses. While the implementation of sustainable criteria in remuneration contracts negatively impacts the banks' riskiness profile and positively impacts its ESG (environmental, social and governance) performance, in opposition to the expected hypothesis, its relationship with the banks' economic performance is negative.

This study contributes to the literature in several ways. First, to the best of our knowledge, this is the first paper that explores the financial and non-financial impacts of the use of sustainability criteria in the banks' executive compensation plans. Second, unlike existing studies that have valorized the adoption of sustainability criteria by means of a dichotomous variable $(1=$ yes; $0=$ no), a more 
comprehensive approach was adopted. Indeed, in this paper, an "ad hoc" governance score, the "ESG remuneration performance rating", was elaborated to proxy the intensity of the use of sustainable remuneration targets by banks. Last, the literature on the use of non-financial targets in remuneration contracts was expanded by providing evidence of their beneficial implications for reducing the financial riskiness and improving the sustainability performance of banks. This is important to investors as well as regulators, especially in light of the recent debate on the banks' compensation reform (EBA 2015).

The paper is structured as follows. In the next section, the theoretical background will be discussed to elaborate the research hypotheses. The method and empirical results will be presented in Secs. 3 and 4, respectively. The discussion of the main findings can be found in Sec. 5 , while Sec. 6 provides the conclusions, the implications and future research lines.

\section{Theoretical Background and Hypotheses Development}

\subsection{Agency theory, sustainability targets and economic performance}

Consistent with agency theory, several scholars have argued that the inclusion of non-financial targets in remuneration contracts is valuable in enhancing the convergence of interests between shareholders and management (Cordeiro \& Sarkis 2008). This occurs because the integration of sustainability criteria in executive compensation can mitigate the managers' myopia and their short-term orientation. Moreover, non-financial performance measures positively impact long-term shareholder value as managers have an incentive to be engaged in more sustainability practices that are characterized by long-term perspectives (Maas \& Rosendaal 2016). Therefore, by linking the managers' remuneration to sustainability practices, firms can also reduce conflicts among all their stakeholders. Indeed, as stated by Flammer et al. (2016), non-financial performance criteria "incentivize managers to pay more attention to stakeholders that have little voice (and hence exert little direct pressure on managers) but are financially material to a firm's operating context and long-term success" (Flammer et al. 2016, p. 4). Overall, remuneration contracts linked to nonfinancial targets are able to produce several important benefits by continually enhancing the firm's economic performance.

These conceptual considerations are confirmed by much empirical research. The first important findings date back to the second half of the 90's. Among these, Ittner \& Larcker (1998), by analyzing the value relevance of non-financial performance measures, found that firm-level customer satisfaction was positively and statistically linked to future financial performance. Thus, they recommended the inclusion of nonfinancial indicators (mainly customer satisfaction) in internal performance measurement systems and remuneration contracts. Similarly, by using time series analysis from 18 hotels managed by a hospitality firm, Banker et al. (2000) document that managerial incentive compensation plans that also include non-financial performance 
measures are significantly associated with future financial performance as measured by individual business unit revenues and operating profit. With regard to financial services firm, by comparing firm with similar strategies and value drivers, Ittner et al. (2003) showed that the more extensive use of non-financial measures was strongly associated with higher stock market returns. Other important and comparable results are found in more recent studies. Abdelmotaal \& Abdel-Kader (2016) found that there is a significant relationship between the use of sustainability incentives and the return on shareholder funds, while Flammer et al. (2016), based on a sample covering all S\&P 500 firms during a 10-year period (2004-2013), document that the integration of ESG criteria in remuneration contracts leads not only to a reduction in short-termism but also to an increase in firm value (measured by Tobin's Q).

In summary, the firm's linkage of compensation to the appropriate use of sustainability performance targets promotes the alignment of managerial action to the firm's vision and can lead to increased firm value and future profits. Therefore, based on these arguments, the first research hypothesis is as follows:

H1. There is a positive relationship between the adoption of sustainability targets in remuneration contracts and the banks' financial performance.

\subsection{Sustainability targets in remuneration contracts and the banks' riskiness profile}

The revised principles on corporate governance for banks issued by Basel Committee on Banking Supervision (BCBS) in 2015 recognize "that remuneration systems form a key component of the governance and incentive structure through which the board and senior management of a bank convey acceptable risk-taking behaviour and reinforce the bank's operating and risk culture" (BCBS 2015, p. 34). In other words, there is a strong relationship between compensation systems and a bank's riskiness profile. Indeed, sound remuneration policies are important tools for promoting effective risk management, for mitigating excessive risk-taking and for pursuing the long-term interests of all stakeholders (EBA 2015, Maas \& Rosendaal 2016). In contrast, "poorly designed remuneration policies have potentially detrimental effects on the sound management of risks, control of risk and the risk-taking behaviour of individuals" (EBA 2015, p. 7).

The existing literature confirmed such linkage. Especially before the sub-prime crisis, incentive mechanisms linked to short-term profit led to the increased riskiness of banks by accentuating their probability of default (Kim et al. 2011). The introduction of rigid rules allowed the mitigation of this perverse process and then the improvement of the banks' risk profile (Cerasi et al., 2017).

Moreover, another stream of research documented that "alternative banks" (banks that pursue ethical, social, sustainable, environmental value) are significantly more stable and prudent risk-takers than conventional banks (Karl 2015). Similarly, Frye et al. (2006) showed that CSR firms are more risk averse than non-CSR firms, 
resulting in a weaker link between CEO pay and firm performance in CSR firms than in non-CSR firms. Finally, other contributions highlighted that firms with better corporate governance tend to experience smaller stock price volatility (Huang et al., 2011). Therefore, if a lower risk profile is generally associated with both greater CSR performance and a better governance system, the inclusion of sustainability targets in remuneration contracts should represent a mitigation tool of excessive risk-taking. Indeed, the long-term orientation of such targets should attenuate any imprudent risk-taking that may undermine shareholder value in the long term (Lee et al. 2017). Undoubtedly, as stated by a growing number of scholars, pay systems should be used to incentivize executive behavior towards sustainability (Goktan 2014). Finally, to confirm this link, some banks stress in their remuneration policy the linkage between sustainability targets and risk-taking. For example, in the last Directors' Remuneration Report (HSBC 2017, p. 143), HSBC stated that "performance is measured against a long-term scorecard. $60 \%$ is based on financial outcomes and $40 \%$ is based on non-financial outcomes, including risk and strategy-related measures". Therefore, based on these arguments, the second research hypothesis is as follows:

H2. There is a negative relationship between the adoption of sustainability targets in remuneration contracts and the banks' riskiness profile.

\subsection{Sustainability targets in remuneration contracts and banks' CSR performance}

A number of studies have examined the associations between the structure of executive compensation and the CSR performance of firms (Mahoney \& Thorn 2006, Deckop et al. 2006). In this vein, Mahoney \& Thorn (2006) suggested a positive association between long-term incentive compensation (i.e. stock options) and the CSR strengths of firms. Similarly, Deckop et al. (2006) found that the firms corporate social performance (CSP) was negatively related to short-term CEO pay and positively related to long-term incentives. In other words, the more firms adopt a long-term focus in CEO remuneration plans, the better the firm's CSP. These contributions documented not only the importance of the executive compensation structure for influencing the top managers' focus on CSR but also an important and positive linkage between long-term incentives and better non-financial performance of firms. Therefore, firms that aim to enhance CSR in the long run should develop managerial remuneration plans mostly based on a long-term perspective (Ji 2015). In other words, "corporations might consider using stock options and other long-term incentives to more effectively motivate CEOs or other executives to achieve CSR objectives" (Callan \& Thomas 2014, p. 224).

Consistent with these studies, other research has recently documented a positive relationship between the adoption of sustainability incentives in executive remuneration plans and the firms' sustainability performance (Abdelmotaal \& Abdel-Kader 2016, Flammer et al. 2016, Velte 2016, Maas 2018). For example, based 
on a sample of 212 firms from the FTSE 350 firms, Abdelmotaal \& Abdel-Kader (2016) showed a greater use of sustainability incentives in compensation contracts, especially for firms adopting sustainability practices (such as the formation of a CSR sustainability committee, the use of a CSR sustainability index, and the development of a sustainability resource efficiency policy). These authors argued this linkage was based on two explanations: on one hand, "firms adopting sustainability practices have a better sustainability information system, which facilitates the use of sustainability measures in compensation contracts"; on the other hand, "the use of sustainability incentives would motivate executives to implement effective sustainability practices" (Abdelmotaal \& Abdel-Kader 2016, p. 322). Accordingly, Eccles et al. (2014) also revealed similar findings: firms that adopted social and environmental policies were likely to tie top executive incentives to sustainability metrics.

Other scholars, however, have documented a more direct and positive impact of sustainability criteria in remuneration contracts on the firms' social and environmental performance (Russo \& Harrison 2005, Flammer et al. 2016, Velte 2016), especially when hard, quantitative CSP targets are adopted rather than soft, qualitative CSP targets (Eurosif 2010, Maas 2018) or when firms are characterized by greater CSR concerns. Berrone \& Gomez-Mejia (2009), indeed, highlighted a positive effect of CSR-linked compensation on the environmental performance of companies, especially firms in high-polluting industries. This positive effect occurred because linking executive remuneration to non-financial metrics urged managers to adopt a longer-time horizon (Flammer et al. 2016) to integrate CSR factors at every hierarchical level in order to improve the overall ethical performance of the firms and to accelerate, in this way, the maturity of incentives (Berrone \& Gomez-Mejia 2009, Hong et al. 2015, Abdelmotaal \& Abdel-Kader 2016). Thus, as stated by Hong et al. (2016, p. 199): "providing executives with direct incentives for CSR is an effective tool to increase firm social performance". Therefore, based on these arguments, the effectiveness of sustainability targets to focus the banks' executives' efforts on CSR performance was tested, and the following research hypothesis was formulated:

H3. There is a positive relationship between the adoption of sustainability targets in remuneration contracts and the banks' sustainability performance.

\section{Methods}

\subsection{Sample and data sources}

The sample includes 42 European global and other systemically important institutions (Global and Other-SIIs) with mean assets of $€ 516.67$ million in December 2017. To select this sample, we started from the entire list of systemically important banks provided by the European Banking Authority (EBA) website for each year under investigation (2013-2017), and then we excluded banks for which information about governance variables and ESG performance was not provided in the Eikon-Thomson Reuters database. In summary, the final sample of 42 European systemically 
Table 1 . The composition of the sample by country.

\begin{tabular}{lrc}
\hline Country of headquarters & $N$ & Percentage of total assets (year 2017) \\
\hline North Europe & $\mathbf{1 5}$ & $\mathbf{3 8 . 2 2}$ \\
UK & 5 & 26.77 \\
Republic of Ireland & 2 & 1.01 \\
Denmark & 3 & 2.71 \\
Norway & 1 & 1.34 \\
Sweden & 4 & 6.39 \\
Western Europe & $\mathbf{1 0}$ & $\mathbf{3 9 . 3 0}$ \\
Austria & 2 & 1.67 \\
Belgium & 2 & 2.22 \\
France & 3 & 22.43 \\
Germany & 2 & 9.01 \\
The Netherlands & 1 & 3.97 \\
Eastern Europe & $\mathbf{3}$ & $\mathbf{0 . 7 1}$ \\
Hungary & 1 & 0.20 \\
Poland & 2 & 0.51 \\
Southern Europe & $\mathbf{1 4}$ & $\mathbf{2 2 . 6 9}$ \\
Cyprus & 1 & 0.11 \\
Greece & 3 & 0.80 \\
Italy & 3 & 8.17 \\
Portugal & 2 & 0.46 \\
Spain & 5 & 13.15 \\
TOTAL & $\mathbf{4 2}$ & $\mathbf{1 0 0}$ \\
\hline
\end{tabular}

important banks resulted from the matching of two sources: the list of all Global and Other-SIIs (EBA website) and the Eikon-Thomson Reuters database. All estimates have been carried out both for the whole sample and for a subsample of the UK and Irish banks. The UK and Irish banks are considered separately because their peculiar culture of disclosure is much stronger than that in Southern European countries.

Table 1 describes the composition of the sample by country. The UK and Irish banks represent $27.8 \%$ of the banking assets in the sample. They are followed by the French banks with $22.4 \%$ of the banking assets, then the Spanish banks with $13.1 \%$, and the German banks with $9.01 \%$. Covering a period of five years (2013-2017), the focus was on the systemically important banks because the adoption of more "sustainable" remuneration plans is typically more relevant for large banks, which are much more exposed to market discipline and stakeholder attention (FSB 2015, 2018). Moreover, the stock market reaction to hard-law remuneration regulation is more intensive for larger banks (Díaz et al. 2017). The time period analyzed starts from 2013 for two reasons. First, although in 2009, the FSB (2009) had already recognized the importance of enhancing all disclosure criteria (including non-financial or sustainability measures) used for performance measurement and risk adjustment, it was only in response to the issuance of Directive 2013/36/EU (European Commission 2013) that Europe implemented binding international principles and standards on banking compensation at the European Union level. Thus, before 2013, the number of banks including non-financial or sustainability measures in their 
disclosures was mostly equal to zero because few banks provided the appropriate information on the ESG performance criteria used in their remuneration packages. Accordingly, we have decided to conduct our research from 2013 by assuming that starting from that period, European banks paid more attention to the issue of remuneration disclosure.

The financial data (in millions of euro) were obtained from Datastream-Thomson Reuters, while the ESG and corporate governance and ESG performance data were collected from Eikon-Thomson Reuters. The information regarding compensation (in millions of euro) levels was hand-collected by consulting the corporate documents of banks, including the Annual Report, the Corporate Governance Report and the Pillar 3 Disclosure.

\subsection{Dependent variable}

To test the three research hypotheses, in the baseline estimation models, different dependent variables were used. Return on assets (ROA) was used to verify the impact of sustainability remuneration targets on the banks' economic performance (Hypothesis 1). This variable was chosen because it represents a good proxy of economic growth and reflects expected future performance (Galbreath 2011). ROA was also used by several scholars (Eccles et al. 2014) to assess the relationships between economic and sustainability performance for the banking sector (Simpson \& Kohers 2002, Forcadell and Aracil 2017, Esteban-Sanchez et al. 2017, Brogi \& Lagasio 2018). The variable NPL\%TL (non-performing loans as a \% of total loans) was used to corroborate the influence of sustainability remuneration targets on the banks' riskiness profile (Hypothesis 2). This dependent variable was chosen because it has been utilized in several studies in order to test the relation between managerial incentives and risk in banks (Cerasi \& Oliviero 2015). Moreover, scholars also documented that non-performing loans were negatively associated with bank sustainability performance (Wu \& Shen 2013). Finally, based on the relationship between sustainability remuneration targets and the banks' non-financial performance, the ESG score was used to test the last research hypothesis. The ESG score was used because it exemplifies one of the major corporate social responsibility performance ratings used to capture the performance achieved by banks with regard to environmental sustainability (Environmental), stakeholders' relations (Social) and corporate governance (Governance) (Cheng et al. 2013, Velte 2016). Additionally, the ESG score was adopted in several studies testing the relationships between sustainability performance and various performance outcomes (governance performance, see Birindelli et al. (2018); environmental performance, see Brogi \& Lagasio (2018)).

\subsection{Independent variables}

\subsubsection{The ESG remuneration performance rating}

To verify the impact of sustainability remuneration targets on the banks' financial performance, riskiness profile and sustainability performance, an "ad hoc" 
Table 2. The model for the development of the "ESG remuneration performance rating".

\begin{tabular}{llc}
\hline & \multicolumn{1}{c}{ Items } & Score \\
\hline 1 & Use of non-financial performance criteria & 1 \\
2 & Number of non-financial performance criteria used & if $<3=0$ \\
& & if $>3=1$ \\
3 & Differentiated valorization of non-financial targets for each executive & 1 \\
4 & Definition of the \% of variable remuneration linked to non-financial performance & 1 \\
5 & Definition of quantitative targets for each non-financial criterion & 1 \\
6 & Balance between non-financial and financial criteria & 1 \\
7 & Balance between non-financial and financial criteria in percentage terms & 1 \\
8 & Use of non-financial criteria at the individual level and/or business unit level & 1 \\
9 & Use of non-financial criteria at the enterprise level & 1 \\
10 & Clawback or malus clauses in the presence of unethical conduct by managers & 1 \\
11 & Inclusion of non-financial metrics within the long-term incentive plans & 1 \\
12 & Use of non-financial criteria also for senior management & 1 \\
\hline
\end{tabular}

governance score, the "ESG remuneration performance rating" (ESG rem), were elaborated. This score is a proxy of the intensity of the use of non-financial metrics in the banks' executive remuneration plans. By adopting the content analysis approach (Krippendorf 2004), a model composed of 12 items was developed (Table 2). To valorize each item, all corporate documents of banks (especially compensation/ remuneration reports, annual reports, and corporate governance reports) were analyzed. While the existing studies on sustainability metrics in executive compensation mainly used a dichotomous variable in order to formalize the adoption of nonfinancial remuneration criteria by the analyzed firms (Abdelmotaal \& Abdel-Kader 2016), we chose to elaborate a more comprehensive explanatory variable to better differentiate the approach followed by each bank and then to strengthen the correctness of the estimations. Indeed, the ESG remuneration performance rating represents the sum of 12 items designed to test the intensity of the banks' adoption and utilization of the non-financial criteria in their executive remuneration schemes. All these elements are equally relevant since they are based on banking compensation regulation or on evidence from the existing literature (see, infra). We picked 12 items in order to capture all the most relevant requirements/recommendations established by the doctrine or by supervisory authorities.

The development of the ESG remuneration performance rating is in line with the previous research methodology adopted by La Porta et al. (1998), Gompers et al. (2003), and Bianchi et al. (2011). More specifically, the ESG-remuneration performance rating was measured on a binary scale that takes the value 1 if the item is disclosed (and thus implemented by a bank) and 0 otherwise. Then, by using the following formulation, the cumulative score was calculated:

ESG-remuneration performance rating

$=$ Number of items disclosed/implemented by bank/Total number of items in the model. 
The attributed scores varied between zero (non-compliance of the items or absence of relative information) and 1 (compliance of the bank with the item). A graduated valuation is only considered for item 2 (if $<3=0$; if $>3=1$ ).

The first items of the model are used to verify whether the bank uses non-financial metrics and, subsequently, the number of non-financial performance criteria adopted (item 2). For this latter item, a graduated valuation is applied in order to appreciate/ valorize banks adopting a greater number of such criteria (more ESG-conscious banks). Since 2009, several regulators (BCBS 2011, EBA 2015, FSB 2017b, 2018) have incentivized banks to take into account the non-financial indicators when determining the level and structure of a director's remuneration. The BCBS — just to cite one - stated that the risk adjusted remuneration process must consider both qualitative and quantitative performance measures. Specifically, "while performance measures are normally focused on financial metrics, it is also important that financial institutions include non-financial metrics in developing the risk-based remuneration hurdles" (BCBS 2011, p. 11). Some examples of non-financial remuneration metrics are the following: customer satisfaction, internal business process efficiency, and people/leadership objectives (BCBS 2011). Regulators have not specified how many non-financial indicators should be used, but there are two good reasons why banks should adopt a sufficient number of these indicators. First, non-financial measures of performance, including conduct-related goals, help signal to employees the importance that management places on the prudent management of risk and acceptable standards of behavior (FSB 2018). Second, "the combination of different metrics (financial and non-financial incentives) might also contribute to reduce the risks of fraud or gaming of the measures" (BCBS 2011, p. 20).

Then, the model investigates if the banks adopt a differentiated valorization of non-financial targets for each executive manager (item 3). Since the functions performed by each executive may differ, it would also be advisable for the non-financial performance indicators to be different to express, correctly the actual contribution offered to the (economic and/or social) value creation of the bank. To support this consideration, the FSB recently confirmed that "well-structured incentive schemes should include the use of qualitative and/or quantitative assessments of an employee's conduct". The FSB added that "specific criteria should vary depending on the underlying nature of activities", pointing out the need to establish a link between the non-financial metrics and the performance characteristics to be assessed (FSB 2017b, p. 9). Similarly, the BCBS stated that "firms should use a combination of financial and non-financial measures to assess employee performance and adapt the measurement to each employee's specific situation" (BCBS 2011, p. 6). Some banks follow this approach. For example, in the Annual Report and Accounts 2017, HSBC includes a table providing an overview of the non-financial performance achieved by the following executives: the Group Chief Executive, the Chief Risk Officer, and the Group Finance Director (HSBC 2017, p. 148). Additionally, for each of these managers, the weighting and the assessment percentages of non-financial criteria are provided. 
The additional items of the model concern the definition of the percentage of variable remuneration linked to non-financial performances (item 4) and the definition of quantitative targets for each non-financial criterion (item 5). These two items reflect the importance of enhancing the disclosures on remuneration packages (FSB 2018) and are used to comply with the regulation that requires the identification of all components of the risk-adjusted remuneration process. To this regard, the European Commission stated that all the performance remuneration criteria, including the non-financial measures, should be predetermined and measurable (European Commission 2009). Moreover, the literature has revealed that compared to the qualitative non-financial measures, the use of quantitative/hard non-financial targets better improves the sustainability performance of firms (Maas 2018). ${ }^{\text {a }}$

Next, the model investigates the balance between financial and non-financial criteria, that is, in determining incentive pay, the weight of non-financial targets compared to that of financial ones. Since the information provided by the banks about this aspect is often different, the model attributes a score equal to 1 if the bank only affirms that it estimates this balance (item 6) and one more point if the banks also quantify this ratio in percentage terms (item 7 ). In this regard, banking regulation also stresses the importance of equally balancing the adoption of financial and non-financial measures by using the balanced scorecard approach (BCBS 2011). For example, the BCBS stated that for executive management, the remuneration performance process should be assessed on the basis of financial (weighted at 60\%) and non-financial metrics (weighted at 40\%) (BCBS 2011).

Finally, the last items of the model focus on the following: (a) the adoption of non-financial criteria at the individual, business unit and enterprise levels (items 8 and 9) as incentive payments must reflect individual performance but also depend on financial results and other measures of value creation at all enterprise levels (EBA 2015 , FSB 2018) ; (b) the adoption of clawback or malus clauses (item 10) in order to stress the linkage of compensation and conduct and to deter misconduct (FSB 2018); (c) the inclusion of non-financial metrics in the long-term incentive plans (item 11) because regulators stress the importance of aligning the remuneration policies with the long-term interests and risk appetite of the banks (European Commission 2009, BCBS 2011), and finally, (d) the extended use of non-financial criteria for senior management incentive schemes (not just for board or executive managers, item 12). Indeed, banking regulation promoted the new compensation rules not only for the executive directors but also for other important managerial figures such as all

\footnotetext{
a As documented by Maas (2018, p. 576), soft or qualitative targets are "often less accurate and reliable than hard or quantitative targets because they are less controllable, less objective and often influenced by the rater's biases".

b More specifically, FSB (2018, p. 16) stated that: "for senior executives as well as other employees whose actions have a material impact on the risk exposure of the firm: a substantial proportion of compensation should be variable and paid on the basis of individual, business-unit and firm-wide measures that adequately measure performance".
} 
material risk-takers and other important employees (who, for example, may present a material risk for the bank's financial soundness on a collective basis) (BCBS 2011).

\subsubsection{Control variables}

Moreover, the following firm-level control variables were added. Some of these are economic variables, while others are governance/ownership variables. More specifically, the total assets (TA), the total capital to total assets (TC\%TA), the CSR strategy score (CSR Strat), the shareholders score (SH score), the management score (MG score), the Tier 1 (T1), the portion of variable share-based remuneration (SB comp), and the percent of shares held by institutional investors (INST own) were included. The total assets (TA) variable measures the bank's size, the total capital to total assets variable (TC\% TA) is a proxy of the bank's leverage, and the CSR strategy score (CSR Strat) proxies the banks' commitment to integrate the economic, social and environmental dimensions into its day-to-day decision-making processes. The shareholders score (SH score) measures a company's effectiveness towards the equal treatment of shareholders, the management score (MG score) measures the efficiency of the banks' corporate governance system, and the Tier 1 (T1) is a proxy of the banks' capitalization. Finally, the portion of variable sharebased compensation (SB comp) gives information on the amount of any form of share-based incentives provided by the bank in both the short and the long terms, while the percent of shares held by institutional investors (INST own) represents the difference between the total percentage of shares outstanding held by all investors and the percentage of shares held by strategic entities (individuals, corporations, holding companies, and government agencies).

In the baseline model 1 (where the dependent variable is ROA), all these variables were included as previous studies offered evidence that economic performance is significantly associated not only with the firms' size (Abdelmotaal \& Abdel-Kader 2016, Maas 2018), the firm's leverage (Said et al. 2003, HassabElnaby et al. 2005) and its capitalization (Switzer et al. 2018) but also with the firms' adoption of sustainability strategies (Karl 2015) and a better corporate governance system (Abdelmotaal \& Abdel-Kader 2016) including stronger shareholder rights (Gompers et al. 2003) and more institutional ownership. Indeed, it is likely that institutional investors, especially short-term institutional investors, can more easily encourage managers to increase shareholder returns by taking more risks (Erkens et al. 2012, Garel \& Romec 2017). Finally, aimed at alleviating the possibility that boards of directors redefine the executives' whole compensation package (or only other components of executive compensation such as stock options) when incorporating sustainability performance criteria, a compensation-level control (the portion of variable share-based remuneration) was included. All these control variables are considered to be strongly associated with the banks' economic performance.

In the baseline model 2 (where the dependent variable is NPL\%TL), the control variables were considered since the previous studies documented that the firms' 
riskiness is significantly associated not only with the firms' size (Abdelmotaal \& Abdel-Kader 2016, Maas 2018) but also with the leverage ratio, capital buffers (Switzer et al. 2018) and the adoption of a CSR strategy (Karl 2015). Moreover, a shareholder and a management score were both added because it was thought that the banks' riskiness is influenced by the efficiency of the corporate governance structure, including the use of anti-takeover devices (Gompers et al. 2003). Previous literature has argued that strong shareholder rights could moderate managerial entrenchment by leading to a reduction in the cost of equity capital and thus the riskiness of the firm (Cheng et al. 2006, Huang et al. 2009). Finally, institutional ownership was also added in model 2 because existing studies showed that higher institutional investors both negatively (Switzer et al. 2018) and positively (Cheng et al. 2015) influence the firms' default probabilities. The share-based compensation level was included because equity incentives are also able to affect the riskiness of the firms.

Finally, in the baseline model 3 (where the dependent variable is the ESG score), the control variables were included because the previous studies documented that high sustainability companies tended to be larger (Chih et al. 2010) and to exhibit a lower leverage ratio, superior capital buffers (Karl 2015), a more efficient corporate governance system (Beltratti 2005) and the adoption of a CSR communication strategy (Eccles et al. 2014). With regard to the shareholder score, according to Mallin \& Melis' (2012) research, stronger shareholders rights can mitigate overall risks and facilitate the achievement of long-term sustainable corporate performance. Finally, other studies have suggested the importance of both the structure of executive compensation (Mahoney \& Thorn 2006) and institutional equity ownership (Faller \& Knyphausen-Aufseß 2018) in encouraging socially responsible actions. For these reasons, the two control variables concerning the total variable share-based remuneration and the percent of shares held by institutional investors were also included in baseline model 3 .

A detailed description of all variables, their definition and their source are provided in Appendix (Table A.1).

\subsection{Descriptive statistics}

Table 3 reports the descriptive statistics of all dependent and independent variables used in the study for (a) the entire sample, for (b) the subsample of UK and Irish banks, and for (c) the subsample of banks in the remaining countries.

Note that the mean of the ESG remuneration performance rating is 45.07 for the entire sample, but it is 65.11 for the subsample of the UK and Irish banks, which indicates that on average, banks in these countries use approximately more than half of the items included in the ESG remuneration performance rating. Moreover, compared to banks in the remaining countries, the UK and Irish banks are larger in terms of total assets, present better sustainability performance (see the mean of the ESG score) and are characterized by better sustainability performance (see the mean 
of the ESG score) but by worse economic performance (see the mean of both the ROA and the ROE). The correlation matrix is reported in the appendix (Table A.2).

\subsection{Econometric approach}

To test hypotheses $\mathrm{H} 1, \mathrm{H} 2$ and $\mathrm{H} 3$, we estimated the following panel regression model (baseline estimation):

$$
\begin{aligned}
Y_{i t}= & \beta_{1}+\beta_{2} \mathrm{ESG} \mathrm{rem}_{i t}+\beta_{3} \mathrm{TA}_{i t}+\beta_{4} \mathrm{TC} \mathrm{TA}_{i t}+\beta_{5} \mathrm{CSR} \text { Strat }+\beta_{6} \mathrm{SH} \text { score } \\
& +\beta_{7} \mathrm{MG} \mathrm{score}_{i t}+\beta_{8} \mathrm{~T} 1+\beta_{9} \mathrm{SB} \mathrm{comp}_{i t}+\beta_{10} \mathrm{INST} \mathrm{own}_{i t}+\varepsilon_{i t},
\end{aligned}
$$

where $y$ represents ROA (baseline model 1), NPL\%TL (baseline model 2), and the ESG score (baseline model 3); $i$ and $t$ denote the bank and the year, and the error terms $\varepsilon_{i t} \sim$ IID $\left(0, \sigma^{2}\right)$ account for possible bank-level stochastic shocks that may affect the dependent variable in each regression. Baseline models 1, 2 and 3 were

\begin{tabular}{|c|c|c|c|c|c|c|}
\hline Variable & Mean & Median & Standard deviation & Minimum & Maximum & Number of observations \\
\hline \multicolumn{7}{|c|}{ (a) Entire sample } \\
\hline ROA & 0.61 & 0.65 & 0.89 & -3.21 & 4.99 & 185 \\
\hline ROE & 2.41 & 5.59 & 25.35 & -225.7 & 83.25 & 210 \\
\hline PTBV & 0.97 & 0.86 & 0.92 & 0.01 & 12.19 & 190 \\
\hline ESG rem & 45.07 & 42 & 27.99 & 0 & 100 & 210 \\
\hline $\mathrm{TA}$ & 52.96 & 26.79 & 57.80 & 1.80 & 225.06 & 210 \\
\hline SH score & 44.56 & 43.51 & 28.45 & 1.14 & 99.10 & 205 \\
\hline MG score & 59.95 & 63.88 & 29.45 & 1.35 & 99.49 & 205 \\
\hline SB comp & 0.60 & 0.018 & 1.35 & 0 & 8.67 & 199 \\
\hline INST own & 30.79 & 30.92 & 18.24 & 0 & 75.83 & 170 \\
\hline Price Vol & 32.65 & 29.57 & 11.65 & 16.01 & 69.06 & 210 \\
\hline NPL\%TL & 7.61 & 4.04 & 10.96 & 0.22 & 60.71 & 173 \\
\hline TC\% TA & 19.43 & 17.43 & 9.58 & 6.07 & 55.85 & 210 \\
\hline CSR Strat & 1.01 & 0.72 & 5.35 & 0.018 & 77.27 & 205 \\
\hline $\mathrm{T} 1$ & 14.95 & 13.9 & 3.55 & 8.17 & 28.70 & 195 \\
\hline ESG score & 68.14 & 72 & 17.07 & 19 & 95 & 205 \\
\hline \multicolumn{7}{|c|}{ (b) Subsample of UK and Irish banks } \\
\hline ROA & 0.40 & 0.36 & 0.60 & -0.76 & 1.62 & 30 \\
\hline ROE & 3.98 & 2.81 & 14.72 & -14.72 & 78.44 & 35 \\
\hline PTBV & 0.83 & 0.80 & 0.28 & 0.08 & 1.45 & 30 \\
\hline ESG rem & 65.11 & 83 & 33.97 & 8 & 100 & 35 \\
\hline $\mathrm{TA}$ & 93.44 & 93.35 & 70.29 & 9.27 & 225.06 & 35 \\
\hline SH score & 29.55 & 23.59 & 23.49 & 1.14 & 78.45 & 35 \\
\hline MG score & 67.43 & 73.34 & 29.06 & 1.35 & 97.36 & 35 \\
\hline SB comp & 1.97 & 0.91 & 2.51 & 0 & 8.67 & 35 \\
\hline INST own & 47.88 & 51.31 & 19.60 & 13.63 & 75.83 & 25 \\
\hline Price Vol & 33.16 & 30.54 & 10.94 & 16.01 & 55.24 & 35 \\
\hline NPL\%TL & 4.27 & 2.62 & 5.03 & 0.22 & 20.34 & 30 \\
\hline TC\% TA & 14.82 & 13.84 & 3.63 & 9.5 & 23.05 & 35 \\
\hline CSR Strat & 0.77 & 0.76 & 0.17 & 0.38 & 0.99 & 35 \\
\hline $\mathrm{T} 1$ & 14.01 & 13.91 & 1.96 & 10.3 & 17.9 & 30 \\
\hline ESG score & 71.26 & 76 & 12.53 & 46 & 88 & 35 \\
\hline
\end{tabular}

Table 3. Descriptive statistics. 
Table 3. (Continued)

\begin{tabular}{lrccccc}
\hline Variable & Mean & Median & Standard deviation & Minimum & Maximum & Number of observations \\
\hline \multicolumn{7}{l}{ (c) Subsample of banks in the remaining countries } \\
ROA & 0.65 & 0.68 & 0.94 & -3.21 & 4.99 & \\
ROE & 2.05 & 5.68 & 27.07 & -225.7 & 83.25 & 154 \\
PTBV & 0.99 & 0.88 & 0.99 & 0.01 & 12.19 & 174 \\
ESG rem & 41.11 & 42 & 24.93 & 0 & 88 & 159 \\
TA & 45.08 & 23.24 & 51.57 & 1.91 & 207.09 & 174 \\
SH score & 47.93 & 50 & 28.32 & 1.72 & 99.10 & 174 \\
MG score & 58.56 & 60.63 & 29.40 & 1.47 & 99.49 & 169 \\
SB comp & 0.31 & 0.001 & 0.65 & 0 & 4.02 & 169 \\
INST own & 27.79 & 29.23 & 16.39 & 0 & 75.48 & 163 \\
Price Vol & 32.61 & 29.5 & 11.83 & 17.77 & 69.06 & 144 \\
NPL\%TL & 8.37 & 4.90 & 11.75 & 0.31 & 60.71 & 174 \\
TC\%TA & 20.15 & 18.33 & 9.81 & 6.84 & 55.85 & 142 \\
CSR Strat & 1.06 & 0.69 & 5.90 & 0.019 & 77.27 & 174 \\
T1 & 15.10 & 13.9 & 3.75 & 8.67 & 28.70 & 169 \\
ESG score & 67.62 & 70 & 17.82 & 21 & 95 & 164 \\
\hline
\end{tabular}

Notes: This table reports summary statistics on ROA, return on equity (ROE), Price to book value (PTBV), ESG remuneration performance rating (ESG rem), total assets (TA), shareholder score (SH score), management score (MG score), share-based compensations (SB comp), percent of shares held by institutional investors (INST own), price volatility (Price Vol), non-performing loans to total loans (NPL\%TL), total capital to total assets (TC\%TA), CSR strategy (CSR Strat), tier 1 ratio (T1) and ESG performance score (ESG score). Data related to the 2013 to 2017 period. Both TA and SB comp are divided by 10 million.

initially estimated for the whole sample and then separately for the subsample of the UK and Irish banks and for the subsample of the banks in the remaining countries. Since due to the possible endogeneity of some explanatory variables, the estimation could produce biased results, we estimated each equation by one-year lagging all regressors. This allowed us to mitigate endogeneity concerns and to control for withinfirm dynamics (Maas 2018). Firm-fixed effects in all three models were included to account for any time-invariant bank characteristics that might affect both the adoption of sustainability targets in banking compensation and bank-level outcomes (unobservable heterogeneity). Moreover, recent literature (see, for instance, Cheng et al. (2015)) has shown that risk measures in banks are highly persistent and that a large amount of variation in bank risk is explained by time-invariant effects at the firm level.

\section{Empirical Results}

The estimations have been carried out by employing the STATA 15 econometric software. The results achieved are reported in Tables $4-6$.

Looking at Table 4, the results show that ROA is not influenced by the variable ESG rem when the sample of banks is considered as a whole (column (a)). However, after splitting our sample, we find evidence of a negative relationship in the case of the UK and Ireland (column (b)) but not in the remaining countries (column (c)). 
Table 4. Estimation results for the baseline model 1. Dependent variable: ROA.

\begin{tabular}{|c|c|c|c|}
\hline & $\begin{array}{l}(\mathrm{a}) \\
\text { All countries }\end{array}$ & $\begin{array}{c}(\mathrm{b}) \\
\mathrm{UK} \text { and Ireland }\end{array}$ & $\begin{array}{l}\text { (c) } \\
\text { Remaining countries }\end{array}$ \\
\hline ESG rem & $\begin{array}{r}-0.003 \\
(0.003)\end{array}$ & $\begin{array}{c}-0.008^{* *} \\
(0.002)\end{array}$ & $\begin{array}{c}-0.001 \\
(0.004)\end{array}$ \\
\hline TA & $\begin{array}{l}0.012^{* *} \\
(0.005)\end{array}$ & $\begin{array}{l}0.040^{* * *} \\
(0.004)\end{array}$ & $\begin{array}{c}0.015^{*} \\
(0.008)\end{array}$ \\
\hline $\mathrm{TC} \% \mathrm{TA}$ & $\begin{array}{c}0.007 \\
(0.0134)\end{array}$ & $\begin{array}{r}-0.038 \\
(0.025)\end{array}$ & $\begin{array}{c}0.005 \\
(0.013)\end{array}$ \\
\hline CSR Strat & $\begin{array}{r}-0.531 \\
(0.517)\end{array}$ & $\begin{array}{l}13.834^{* * *} \\
(1.882)\end{array}$ & $\begin{array}{r}-0.701 \\
(0.538)\end{array}$ \\
\hline SH score & $\begin{array}{c}-0.007^{*} \\
(0.004)\end{array}$ & $\begin{array}{l}-0.068^{* * *} \\
(0.005)\end{array}$ & $\begin{array}{r}-0.007 \\
(0.005)\end{array}$ \\
\hline MG score & $\begin{array}{c}0.004 \\
(0.004)\end{array}$ & $\begin{array}{l}0.011^{*} \\
(0.005)\end{array}$ & $\begin{array}{c}0.003 \\
(0.005)\end{array}$ \\
\hline $\mathrm{T} 1$ & $\begin{array}{r}-0.008 \\
(0.031)\end{array}$ & $\begin{array}{r}-0.016 \\
(0.002)\end{array}$ & $\begin{array}{r}-0.017 \\
(0.035)\end{array}$ \\
\hline SB comp & $\begin{array}{c}0.008 \\
(0.037)\end{array}$ & $\begin{array}{l}0.239^{* * *} \\
(0.024)\end{array}$ & $\begin{array}{c}0.108 \\
(0.068)\end{array}$ \\
\hline INST own & $\begin{array}{l}0.019^{* * *} \\
(0.006)\end{array}$ & $\begin{array}{l}-0.026^{* * *} \\
(0.004)\end{array}$ & $\begin{array}{l}0.020^{* * *} \\
(0.007)\end{array}$ \\
\hline Const & $\begin{array}{r}-0.090 \\
(0.787)\end{array}$ & $\begin{array}{l}-9.892^{* * *} \\
(1.672)\end{array}$ & $\begin{array}{c}0.069 \\
(0.816)\end{array}$ \\
\hline$R$-squared (within) & 0.14 & 0.99 & 0.14 \\
\hline
\end{tabular}

Notes: Fixed-effects estimations. ${ }^{* * *}, * *, *$ indicate, respectively, $1 \%, 5 \%, 10 \%$ of significance. Robust standard errors in parentheses.

At the same time, we find that TA and INST own are statistically significant in all three estimations (although with a different sign), TC\% TA and T1 are never significant, and the remaining control variables are overall significant in the case of the UK and Irish banks. Turning our analysis to Table 5, the results suggest that the ESG rem variable negatively affects NPL\%TL although the set of control variables employed does not produce results that are statistically significant. No evidence of a possible relationship between ESG rem and NPL\%TL is found in the subsample of the UK and Ireland and in that of the other remaining countries. Finally, looking at Table 6, note that ESG rem in both the whole sample and in the subsample of the UK and Irish banks positively affects the ESG score, which is also positively influenced by TA and T1 and, only in the whole sample, by the MG score and by SB comp. Overall, therefore, these findings seem to provide evidence that the adoption of sustainability targets in remuneration contracts negatively affects the banks' financial performance — but only in the UK and Ireland - as well as the banks' riskiness profile; moreover, in the whole sample and in the subsample of the UK and Irish banks, the adoption of sustainability targets in remuneration contracts positively influences the banks' sustainability performance. 
Table 5. Estimation results for the baseline model 2. Dependent variable: NPL\%TL.

\begin{tabular}{|c|c|c|c|}
\hline & $\begin{array}{c}(\mathrm{a}) \\
\text { All countries }\end{array}$ & $\begin{array}{c}(\mathrm{b}) \\
\mathrm{UK} \text { and Ireland }\end{array}$ & $\begin{array}{c}\text { (c) } \\
\text { Remaining countries }\end{array}$ \\
\hline ESG rem & $\begin{array}{c}-0.085^{* *} \\
(0.041)\end{array}$ & $\begin{array}{r}-0.190 \\
(0.101)\end{array}$ & $\begin{array}{r}-0.047 \\
(0.033)\end{array}$ \\
\hline TA & $\begin{array}{r}-0.034 \\
(0.046)\end{array}$ & $\begin{array}{c}0.093 \\
(0.061)\end{array}$ & $\begin{array}{r}-0.156 \\
(0.095)\end{array}$ \\
\hline $\mathrm{TC} \% \mathrm{TA}$ & $\begin{array}{c}0.065 \\
(0.102)\end{array}$ & $\begin{array}{r}-0.007 \\
(0.734)\end{array}$ & $\begin{array}{c}0.043 \\
(0.099)\end{array}$ \\
\hline CSR Strat & $\begin{array}{c}0.382 \\
(2.480)\end{array}$ & $\begin{array}{l}52.655^{* *} \\
(16.562)\end{array}$ & $\begin{array}{c}0.238 \\
(2.576)\end{array}$ \\
\hline SH score & $\begin{array}{c}0.032 \\
(0.036)\end{array}$ & $\begin{array}{r}-0.198^{*} \\
(0.089)\end{array}$ & $\begin{array}{c}0.025 \\
(0.042)\end{array}$ \\
\hline MG score & $\begin{array}{c}0.002 \\
(0.018)\end{array}$ & $\begin{array}{r}-0.061 \\
(0.040)\end{array}$ & $\begin{array}{c}0.008 \\
(0.018)\end{array}$ \\
\hline $\mathrm{T} 1$ & $\begin{array}{r}-0.165 \\
(0.148)\end{array}$ & $\begin{array}{r}-0.432 \\
(0.259)\end{array}$ & $\begin{array}{r}-0.113 \\
(0.157)\end{array}$ \\
\hline SB comp & $\begin{array}{r}-0.094 \\
(0.175)\end{array}$ & $\begin{array}{c}0.764 \\
(0.516)\end{array}$ & $\begin{array}{c}-0.460 * * \\
(0.265)\end{array}$ \\
\hline INST own & $\begin{array}{r}-0.013 \\
(0.029)\end{array}$ & $\begin{array}{c}-0.299 \\
(0.208)\end{array}$ & $\begin{array}{r}-0.029 \\
(0.035)\end{array}$ \\
\hline Const & $\begin{array}{l}13.572^{* * *} \\
(5.786)\end{array}$ & $\begin{array}{l}-3.087 \\
(22.984)\end{array}$ & $\begin{array}{l}17.700 * * \\
(7.022)\end{array}$ \\
\hline$R$-squared (within) & 0.16 & 0.78 & 0.15 \\
\hline
\end{tabular}

Notes: Fixed-effects estimations. ***, **, * indicate, respectively, 1\%, 5\%, 10\% of significance. Robust standard errors in parentheses.

\subsection{Robustness checks}

To strengthen our results, we carried out a number of robustness checks by testing these models with the use of alternative dependent variables. In particular, we reestimated the baseline models 1 and 2 by using ROE and PTBV in place of ROA and Price Vol in place of NPL\%TL. The corresponding results are reported in Tables 7 and 8 , respectively.

Looking at Table 7, the results seem to confirm that the banks' financial performance is negatively affected by the adoption of sustainability targets in remuneration contracts only in the UK and Ireland subsample, since the coefficient of ESG rem is negative and statistically significant when both the ROE and the PTBV are employed as dependent variables. Similarly, the estimation results suggest the existence of a negative relationship between the adoption of sustainability targets and the banks' riskiness profile in the whole sample when Price Vol replaces NPL\%TL. In this case, some control variables ( $\mathrm{SH}$ score and $\mathrm{SB}$ comp) turn significant, strengthening thus our overall findings. The robustness checks, therefore, seem to provide evidence that the estimations of models (1) and (2) are stable and robust 
Table 6. Estimation results for the baseline model 3. Dependent variable: ESG score.

\begin{tabular}{lccc}
\hline & $(\mathrm{a})$ & $(\mathrm{b})$ & $(\mathrm{c})$ \\
& All countries & UK and Ireland & Remaining countries \\
\hline ESG rem & $0.172^{*}$ & $0.535^{* *}$ & 0.131 \\
TA & $(0.100)$ & $(0.1929)$ & $(0.120)$ \\
& $0.146^{*}$ & $0.345^{* *}$ & 0.098 \\
TC\%TA & $(0.081)$ & $(0.085)$ & $(0.141)$ \\
& -0.305 & 0.918 & -0.316 \\
CSR Strat & $(0.215)$ & $(1.497)$ & $(0.218)$ \\
& 1.243 & -10.913 & 0.652 \\
SH score & $(6.214)$ & $(56.365)$ & $(6.974)$ \\
& 0.006 & 0.019 & 0.0124 \\
MG score & $(0.033)$ & $(0.312)$ & $0.035)$ \\
T1 & $0.102^{* * *}$ & 0.025 & $(0.037)$ \\
SB comp & $(0.034)$ & $(0.140)$ & 0.451 \\
& $0.585^{*}$ & $2.117^{*}$ & $(0.393)$ \\
INST own & $(0.355)$ & $(0.785)$ & $1.574^{* *}$ \\
Const & $0.457^{*}$ & 1.050 & $(0.634)$ \\
& $(0.244)$ & $(1.002)$ & -0.056 \\
$R$-squared (within) & -0.090 & -0.160 & $(0.079)$ \\
\hline
\end{tabular}

Notes: Fixed-effects estimations. $* * *, * *, *$ indicate, respectively, $1 \%, 5 \%, 10 \%$ of significance. Robust standard errors in parentheses.

even when alternative measures of the banks' financial performance and of their riskiness profile are used in the regression models.

\subsection{Discussion}

This study results in some important findings that enrich the knowledge about the use of non-financial metrics in the banks' managerial remuneration plans. In summary, the results reveal that the implementation of sustainable criteria in banks' remuneration contracts (i) negatively impacts economic performance, (ii) negatively impacts the riskiness profile, and (iii) positively impacts non-financial performance.

The first hypothesis predicts a positive relationship between the ESG-remuneration performance rating and banks' financial performance. It was expected that firms with a high ESG-remuneration performance rating — indicating that these firms make greater use of non-financial metrics in remuneration — would have higher profitability performance as measured by their ROA. This expectation is consistent with the previous studies (Ittner \& Larcker 1998, Banker et al. 2000, Ittner et al. 2003, Abdelmotaal \& Abdel-Kader 2016, Flammer et al. 2016). Based on the results, hypothesis 1 is rejected. Therefore, a positive effect of an ESGremuneration performance rating on ROA cannot be detected in this study. The results show a significant but negative relationship between the examined variables 
Table 7. Estimation results for the baseline model 1 using ROE and PTBV as dependent variables.

\begin{tabular}{|c|c|c|c|c|c|c|}
\hline & \multicolumn{3}{|c|}{ Dep. Variable: ROE } & \multicolumn{3}{|c|}{ Dep. Variable: PTBV } \\
\hline & $\begin{array}{c}\text { (a) } \\
\text { All } \\
\text { countries }\end{array}$ & $\begin{array}{c}\text { (b) } \\
\text { UK and } \\
\text { Ireland }\end{array}$ & $\begin{array}{c}(\mathrm{c}) \\
\text { Remaining } \\
\text { countries }\end{array}$ & $\begin{array}{c}\text { (a) } \\
\text { All } \\
\text { countries }\end{array}$ & $\begin{array}{l}\text { (b) } \\
\text { UK and } \\
\text { Ireland }\end{array}$ & $\begin{array}{c}\text { (c) } \\
\text { Remaining } \\
\text { countries }\end{array}$ \\
\hline ESG rem & $\begin{array}{c}-0.064 \\
(0.097)\end{array}$ & $\begin{array}{c}-0.405^{* * *} \\
(0.170)\end{array}$ & $\begin{array}{c}0.025 \\
(0.103)\end{array}$ & $\begin{array}{c}0.007 \\
(0.015)\end{array}$ & $\begin{array}{c}-0.017^{*} \\
(0.008)\end{array}$ & $\begin{array}{c}0.014 \\
(0.017)\end{array}$ \\
\hline TA & $\begin{array}{c}0.016 \\
(0.111)\end{array}$ & $\begin{array}{c}0.094 \\
(0.174)\end{array}$ & $\begin{array}{c}-0.118 \\
(0.203)\end{array}$ & $\begin{array}{c}0.042 \\
(0.036)\end{array}$ & $\begin{array}{c}0.013 \\
(0.004)\end{array}$ & $\begin{array}{c}0.074 \\
(0.064)\end{array}$ \\
\hline $\mathrm{TC} \% \mathrm{TA}$ & $\begin{array}{c}-1.436^{* * *} \\
(0.472)\end{array}$ & $\begin{array}{r}-2.33 \\
1.433\end{array}$ & $\begin{array}{c}-1.483^{* * *} \\
(0.466)\end{array}$ & $\begin{array}{c}0.022 \\
(0.024)\end{array}$ & $\begin{array}{c}0.085 \\
(0.052)\end{array}$ & $\begin{array}{c}0.024 \\
(0.026)\end{array}$ \\
\hline CSR Strat & $\begin{array}{c}-10.186 \\
(14.5459)\end{array}$ & $\begin{array}{l}30.276 \\
18.619\end{array}$ & $\begin{array}{c}-11.874 \\
(16.217)\end{array}$ & $\begin{array}{c}0.322 \\
(0.558)\end{array}$ & $\begin{array}{c}1.615 \\
(1.627)\end{array}$ & $\begin{array}{c}-0.334 \\
(0.482)\end{array}$ \\
\hline SH score & $\begin{array}{c}-0.098 \\
(0.071)\end{array}$ & $\begin{array}{c}-0.343^{* *} \\
0.122\end{array}$ & $\begin{array}{c}-0.087 \\
(0.081)\end{array}$ & $\begin{array}{c}-0.014 \\
(0.011)\end{array}$ & $\begin{array}{c}-0.013 \\
(0.008)\end{array}$ & $\begin{array}{c}-0.015 \\
(0.011)\end{array}$ \\
\hline MG score & $\begin{array}{c}0.048 \\
(0.080)\end{array}$ & $\begin{array}{r}-0.028 \\
0.050\end{array}$ & $\begin{array}{c}0.048 \\
(0.086)\end{array}$ & $\begin{array}{c}0.002 \\
(0.003)\end{array}$ & $\begin{array}{c}-0.004 \\
(0.003)\end{array}$ & $\begin{array}{c}0.002 \\
(0.003)\end{array}$ \\
\hline $\mathrm{T} 1$ & $\begin{array}{c}0.150 \\
(1.078)\end{array}$ & $\begin{array}{r}-0.790 \\
0.542\end{array}$ & $\begin{array}{r}0.0527 \\
(1.205)\end{array}$ & $\begin{array}{c}0.001 \\
(0.019)\end{array}$ & $\begin{array}{c}0.010 \\
(0.0169)\end{array}$ & $\begin{array}{c}-0.023 \\
(0.027)\end{array}$ \\
\hline SB comp & $\begin{array}{c}-0.153 \\
(0.507)\end{array}$ & $\begin{array}{l}0.026 \\
0.898\end{array}$ & $\begin{array}{c}0.413 \\
(1.029)\end{array}$ & $\begin{array}{c}0.125 \\
(0.111)\end{array}$ & $\begin{array}{c}0.060 \\
(0.051)\end{array}$ & $\begin{array}{c}0.408 \\
(0.391)\end{array}$ \\
\hline INST own & $\begin{array}{l}0.663^{* *} \\
(0.279)\end{array}$ & $\begin{array}{l}0.301 \\
0.231\end{array}$ & $\begin{array}{l}0.716^{* *} \\
(0.341)\end{array}$ & $\begin{array}{c}0.002 \\
(0.005)\end{array}$ & $\begin{array}{c}-0.001 \\
(0.021)\end{array}$ & $\begin{array}{r}-0.000 \\
(0.005)\end{array}$ \\
\hline Const & $\begin{array}{c}19.527 \\
(19.008)\end{array}$ & $\begin{array}{l}39.132 \\
52.930\end{array}$ & $\begin{array}{c}26.570 \\
(18.967)\end{array}$ & $\begin{array}{c}-1.893 \\
(2.983)\end{array}$ & $\begin{array}{c}-1.169 \\
(1.891)\end{array}$ & $\begin{array}{c}-2.515 \\
(3.402)\end{array}$ \\
\hline$R$-squared (within) & 0.23 & 0.81 & 0.24 & 0.06 & 0.84 & 0.10 \\
\hline
\end{tabular}

Notes: Fixed-effects estimations. $* * *, * *, *$ indicate, respectively, 1\%, 5\%, $10 \%$ of significance. Robust standard errors in parentheses.

although only for the subsample of the UK and Irish banks: the higher the bank's ESG-remuneration performance rating is, the lower its financial performance.

This is quite problematic because it weakens the incentives for firms to use nonfinancial targets in remuneration. There are two possible explanations for the contradiction of this finding with the hypothesis. First, the contradiction might be explained by the differences in the measures used as proxies for firm profitability in this study compared to those used in other studies. Indeed, in this study, accounting metrics were mainly used (ROA and ROE), while other authors used market metrics predominantly (e.g. stock market returns). Another possible explanation is that banks with a high ESG-remuneration performance rating will have better social performance (see hypothesis 3 ). This could be associated, in an early stage, with high investments and high costs linked to the adoption of sustainability practices that negatively impact the banks' profitability. For example, the implementation of a sustainability strategy requires the development of a CSRintegrated reporting system and could require the acquisition of certification. The costs associated with investments in innovation and in CSR-compliant processes can be considerable. 
Table 8. Estimation results for the baseline model 2 using Price Vol as dependent variable.

\begin{tabular}{|c|c|c|c|}
\hline & $\begin{array}{l}\text { (a) } \\
\text { All countries }\end{array}$ & $\begin{array}{c}\text { (b) } \\
\text { UK and Ireland }\end{array}$ & $\begin{array}{c}\text { (c) } \\
\text { Remaining countries }\end{array}$ \\
\hline ESG rem & $\begin{array}{c}-0.065^{*} \\
(0.036)\end{array}$ & $\begin{array}{c}-0.002 \\
(0.091)\end{array}$ & $\begin{array}{c}-0.046 \\
(0.042)\end{array}$ \\
\hline $\mathrm{TA}$ & $\begin{array}{c}-0.033 \\
(0.031)\end{array}$ & $\begin{array}{c}0.025 \\
(0.075)\end{array}$ & $\begin{array}{c}-0.086^{* *} \\
(0.042)\end{array}$ \\
\hline $\mathrm{TC} \% \mathrm{TA}$ & $\begin{array}{r}-0.002 \\
(0.071)\end{array}$ & $\begin{array}{c}0.927 \\
(0.965)\end{array}$ & $\begin{array}{c}0.003 \\
(0.065)\end{array}$ \\
\hline CSR Strat & $\begin{array}{r}-0.737 \\
(2.655)\end{array}$ & $\begin{array}{l}-5.898 \\
(18.703)\end{array}$ & $\begin{array}{c}0.454 \\
(2.771)\end{array}$ \\
\hline SH score & $\begin{array}{l}0.035^{* *} \\
(0.016)\end{array}$ & $\begin{array}{c}0.084 \\
(0.098)\end{array}$ & $\begin{array}{c}0.027 \\
(0.017)\end{array}$ \\
\hline MG score & $\begin{array}{l}0.005 \\
(0.0169)\end{array}$ & $\begin{array}{r}-0.033 \\
(0.051)\end{array}$ & $\begin{array}{c}0.013 \\
(0.018)\end{array}$ \\
\hline $\mathrm{T} 1$ & $\begin{array}{c}-0.178 \\
(0.133)\end{array}$ & $\begin{array}{c}0.153 \\
(0.448)\end{array}$ & $\begin{array}{c}-0.160 \\
(0.144)\end{array}$ \\
\hline SB comp & $\begin{array}{l}-0.343^{* * *} \\
(0.082)\end{array}$ & $\begin{array}{r}-0.119 \\
(0.628)\end{array}$ & $\begin{array}{r}-0.532^{*} \\
(0.283)\end{array}$ \\
\hline INST own & $\begin{array}{c}0.058 \\
(0.053)\end{array}$ & $\begin{array}{r}-0.082 \\
(0.198)\end{array}$ & $\begin{array}{c}0.074 \\
(0.056)\end{array}$ \\
\hline Const & $\begin{array}{l}36.136^{* * *} \\
(3.364)\end{array}$ & $\begin{array}{c}23.009 \\
(29.636)\end{array}$ & $\begin{array}{l}35.759^{* * *} \\
(3.104)\end{array}$ \\
\hline$R$-squared (within) & 0.15 & 0.58 & 0.155 \\
\hline
\end{tabular}

Notes: Fixed-effects estimations. ***,**,* indicate, respectively, 1\%, 5\%, $10 \%$ of significance. Robust standard errors in parentheses.

The second hypothesis predicts a negative relationship between the percentage of non-performing loans to total loans and the ESG-remuneration performance rating. These results confirm the hypothesis. Demonstrating that the inclusion of nonfinancial metrics in board remuneration reduces the firms' non-performing loans to total loans, the results are consistent with hypothesis 2 . Therefore, banks that adopt sustainability targets in remuneration contracts have a lower risk profile. This result is also consistent with recent international and European regulation provisions on bankers' remuneration aimed at limiting the excessive risk-taking of management. Indeed, the regulators' attention to bankers' remuneration originated after the international financial crisis of 2007. Bank governance and remuneration policies were considered one of the possible causes of the crisis (Iannuzzi 2013 for a review). The high level of bankers' compensation was considered to have been too generous in the context of the banks' low performance during the crisis (Ferrarini 2017). An international debate upon the relevance of bankers' pay in the financial crisis has arisen both in an academic context and at a political and institutional levels. Many authors investigated the role of incentives in the crisis (Bebchuk et al. 2010, 
Fahlenbrach \& Stulz 2010, Barontini et al. 2013, Levina 2014). The main question investigated was whether inappropriate remuneration practices in the financial services industry-induced excessive risk-taking and, thus, contributed to the significant losses of major financial intermediaries. Although this regulation does not appear to be completely justified (Ferrarini \& Ungureanu 2011), ${ }^{\mathrm{c}}$ it seems that the previous question can be affirmatively answered. Consequently, numerous principles, standards and rules concerning sound remuneration policies have been promoted on an international (FSB 2010, 2013, 2017a, 2018) and European levels. ${ }^{\mathrm{d}}$ From a regulatory perspective, the use of sustainability measures in banking compensation could also neutralize the risk of misconduct (FSB 2017a). Such targets strengthen the overall risk adjustment process of remuneration practices by introducing " $a$ different lens through which performance is measured" (BCBS 2011, p. 18). A bad nonfinancial performance (in particular, unethical or non-compliant behavior) cannot be compensated for by good financial performance (in terms of profit generation) and diminished compensation. Compensation should be fully aligned with the institution's risk policy in the medium and long terms, providing the right incentives (BCBS 2010). In addition to this, EBA's guidelines stated that "institutions should set and document both quantitative and qualitative, including financial and nonfinancial, performance criteria for individuals, business units and the institution. The performance criteria should not incentivize excessive risk taking or the mis-selling of products" (EBA 2015, p. 64). The new regulations try to overcome the dramatic consequences of a short-term incentives-based system by promoting a better balance between short- and long-term incentives in not only the CEO's compensation but also in that of all bank employees involved in risk-taking activities. ${ }^{\mathrm{e}}$

The third hypothesis predicts a positive relationship between the adoption of sustainability targets in remuneration contracts and the banks' sustainability performance. A few studies have analyzed the effect on the non-financial performance of firms of the use of non-financial targets in remuneration plans. Contrary to expectations, a previous study that analyzed whether Corporate Social Performance (CSP) could be considered as a predictor or a consequence of the use of CSP targets, concluded that (i) the use of CSP targets in general does not automatically lead to

\footnotetext{
${ }^{\mathrm{c}}$ The authors argue that the case for regulating the structure of the bankers' pay is rather weak, while the regulation of remuneration risk governance and remuneration disclosure are to some extent justified.

$\mathrm{d}$ At the European level, the EU adopted a regulatory approach, implementing two directives. The supervisory role was more marginal than that applied in other jurisdictions. However, in addition to the directives, the CEBS, before, and the EBA, after, provided guidelines in order to facilitate the application of the principles included in the directives. The CEBS - Committee of European Banking Supervisors is an independent advisory group on banking supervision in the European Union (EU). It was established by the European Commission in 2004 by Decision 2004/5/EC. On 1 January 2011, this committee was succeeded by the EBA, which took over all existing and ongoing tasks and responsibilities of the CEBS. The EBA was established by Regulation (EC) No. 1093/2010 of the European Parliament and of the Council of 24 November 2010.

e The Regulatory Technical Standards (RTS) on the criteria used to identify categories of staff whose professional activities have a material impact on an institution's risk profile were published by the European Commission as Delegated Act on 6 June 2014.
} 
better CSP results, (ii) while the use of quantitative, hard CSP targets is an effective way to improve CSP results, especially to lower CSP weaknesses (Maas 2018). Therefore, the author partially succeeded in demonstrating the positive effect of sustainability targets in remuneration on the non-financial performance of firms.

Our results reveal that ESG-remuneration performance rating positively affects the ESG score of banks. Therefore, this finding empirically confirms the theoretical arguments that sustainability targets enhance the governance of a company (Abdelmotaal \& Abdel-Kader 2016). The explanations for this evidence could be related to the managers' incentive to adopt a longer-time horizon. In addition to this, it could be attributed to a greater attention paid to stakeholders who contribute to long-term value creation but have little voice and less salient claims. The use of sustainability incentives could motivate executives to implement effective sustainability practices (Abdelmotaal \& Abdel-Kader 2016). This result is very relevant in light of the possible implications that it could have on banking compensation practices. These findings seem to support and justify the regulatory reform initiatives that promoted the use of sustainability targets in remuneration. The results appear to be more significant for the subsample of the UK and Irish banks: This is probably due to their peculiar culture of disclosure that is much stronger than that in Southern European countries. Additionally, the results also showed that the ESG score is positively related to Tier 1 capital in both the whole sample and in the subsample of the UK and Irish banks. In line with these expectations, more capitalized banks perform better in terms of sustainability management. This is probably due to a greater investment capacity of these banks.

\section{Conclusions, Implications, and Future Research Lines}

Remuneration contracts including sustainability metrics are able to produce several important benefits by lastingly enhancing the firm's economic performance (Said et al. 2003, HassabElnaby et al. 2005). The integration of non-financial targets in executive compensation can mitigate the managers' myopia and their short-term orientation. Moreover, by linking the managers' remuneration to sustainability practices, firms can also reduce conflicts among all their stakeholders (Flammer et al. 2016). In this research, the relationships between the adoption of sustainability criteria in remuneration contracts and the financial and non-financial performance of banks were analyzed. Although it has been recognized by regulators and several scholars that including sustainability metrics in remuneration plans lead to positive implications in terms of refocusing to long-term strategy and improving financial and non-financial performance, the extant literature on this topic is largely focused on the US context, on a pre-crisis time window and on non-financial firms. This paper focuses on 42 European, systemically important banks and is based on a five-year panel dataset (from 2013 to 2017).

The findings of this research have possible implications that may be useful for both banks and regulators. The most important practical implication of this research 
is that the findings present an encouragement for the use of sustainability targets in executive compensation, outlining two reasons why this would be beneficial. First, the inclusion of these kinds of metrics in executive compensation stimulates the adoption of long-term strategies rather than the excessive risk-taking behaviors derived from a short-term orientation. This is an advantage for banks in terms of risk reduction. Second, the use of sustainability targets in remuneration incentives improves non-financial performance. Based on these results, regulators are expected to move in the direction of strengthening the use of non-financial criteria.

However, there are several limitations to this study that may be addressed in future research. As the analysis only covers a small period (a five-year period), it offers limited insight into the examined relationships. In the future, it could be useful to extend the time horizon of observation. Second, the sample only includes European, global and other systemically important institutions. These kinds of banks present some peculiarities in terms of size and visibility. Systemically important banks indeed are typically large banks and are particularly exposed to market discipline and to stakeholder attention. It might be questioned whether these conclusions also hold for smaller banks or banks from other regions. As such, some caution is needed in generalizing these results. In addition, it must be noted that the heterogeneity of the samples affects the comparability of this study with previous studies. Unlike other research, this analysis is focused on the banking sector. This implies some specificities. Furthermore, regulation on corporate governance could vary according to the countries. Third, there may be other factors to explain the variation in the banks' profitability that are not tested in this study. Last, this research relies on the measures developed by Eikon-Thomson Reuters. It might be questioned whether non-financial performance can be captured fully by these measures.

This study aims to take a first step in the direction to better understand the relationship between sustainability metrics in remuneration and the financial and non-financial performance of banks, encouraging other researchers to fill the identified gaps.

\section{Appendix A}

Table A.1. Measurement of all dependent and independent variables.

\begin{tabular}{|c|c|c|c|}
\hline Variable & Measure & Label & Source \\
\hline \multicolumn{4}{|c|}{ Dependent variable } \\
\hline Return on assets & Net Income/Total Assets & ROA & Datastream \\
\hline Return on equity & Net income/shareholder's equity & ROE & Datastream \\
\hline $\begin{array}{l}\text { Price to book } \\
\text { value }\end{array}$ & Stock price per share/Book value per share & PTBV & Datastream \\
\hline Price volatility & $\begin{array}{l}\text { A stock's average annual price movement to a } \\
\text { high and low from a mean price for each year* }\end{array}$ & Price Vol & Datastream \\
\hline
\end{tabular}


Table A.1. (Continued)

\begin{tabular}{|c|c|c|c|}
\hline Variable & Measure & Label & Source \\
\hline $\begin{array}{l}\text { Non-performing } \\
\text { loans \% total } \\
\text { loans }\end{array}$ & $\begin{array}{l}\text { The amount of non-performing loans in a bank's } \\
\text { loan portfolio as a percentage of the total } \\
\text { amount of loans the bank holds }\end{array}$ & NPL\%TL & Datastream \\
\hline \multirow[t]{2}{*}{$\begin{array}{l}\text { Environmental, } \\
\text { Social, Gov- } \\
\text { ernance score }\end{array}$} & $\begin{array}{l}\text { An overall company score based on the self- } \\
\text { reported information in the environmental, } \\
\text { social and corporate governance pillars** }\end{array}$ & ESG score & $\begin{array}{l}\text { Eikon-Thomson } \\
\text { Reuters }\end{array}$ \\
\hline & Independent variables & & \\
\hline $\begin{array}{l}\text { ESG remunera- } \\
\text { tion perfor- } \\
\text { mance rating }\end{array}$ & $\begin{array}{l}\text { A proxy of the intensity of the use of non- } \\
\text { financial metrics in the banks' executive } \\
\text { remuneration plans }\end{array}$ & ESG rem & $\begin{array}{l}\text { Content analysis } \\
\text { approach }\end{array}$ \\
\hline Total assets & Total assets (euro) of the bank/10 million & TA & Datastream \\
\hline $\begin{array}{l}\text { Total capital to } \\
\text { total assets }\end{array}$ & $\begin{array}{l}\text { Total capital as a percentage of total assets } \\
\quad \text { (proxy for bank's leverage) }\end{array}$ & $\mathrm{TC} \% \mathrm{TA}$ & Datastream \\
\hline Tier 1 & $\begin{array}{l}\text { The primary capital (shares and common stock) } \\
\text { supporting the lending and deposit activities } \\
\text { of a bank. }\end{array}$ & $\mathrm{T} 1$ & Datastream \\
\hline $\begin{array}{l}\text { CSR strategy } \\
\quad \text { score }\end{array}$ & $\begin{array}{l}\text { A company's practices that communicate that } \\
\text { the company integrates the economic (finan- } \\
\text { cial), social and environmental dimensions } \\
\text { into its day-to-day decision-making processes } \\
\text { (calculated based on } 8 \text { comparable and critical } \\
\text { measures***) }\end{array}$ & CSR Strat & Datastream \\
\hline $\begin{array}{l}\text { Shareholders } \\
\text { score }\end{array}$ & $\begin{array}{l}\text { A company's effectiveness towards equal } \\
\text { treatment of shareholders and the use of } \\
\text { anti-takeover devices (calculated based on } \\
12 \text { comparable and critical measures***) }\end{array}$ & $\mathrm{SH}$ score & Datastream \\
\hline $\begin{array}{l}\text { Management } \\
\text { score }\end{array}$ & $\begin{array}{l}\text { A company's commitment and effectiveness } \\
\text { towards following best practice corporate } \\
\text { governance principles (calculated based on } \\
34 \text { comparable and critical measures***) }\end{array}$ & MG score & Datastream \\
\hline $\begin{array}{l}\text { The portion of } \\
\text { variable } \\
\text { share-based } \\
\text { compensation }\end{array}$ & $\begin{array}{l}\text { The amount in euro of any form of share-based } \\
\text { incentives (including stock options plans, } \\
\text { shares allotment or other share-based incen- } \\
\text { tive systems) provided by the bank in both } \\
\text { the short and long terms }\end{array}$ & SB comp & $\begin{array}{c}\text { Banks' Corporate } \\
\text { documents }\end{array}$ \\
\hline $\begin{array}{l}\text { Percent of shares } \\
\text { held by insti- } \\
\text { tutional } \\
\text { investors }\end{array}$ & $\begin{array}{l}\text { The difference between the total percentage of } \\
\text { shares outstanding held by all investors and } \\
\text { the percent of shares held by strategic entities } \\
\text { (individuals, corporations, holding companies } \\
\text { and government agencies) }\end{array}$ & INST own & $\begin{array}{l}\text { Eikon-Thomson } \\
\text { Reuters }\end{array}$ \\
\hline
\end{tabular}

*For example, a stock's price volatility of $20 \%$ indicates that the stock's annual high and low price has shown a historical variation of $+20 \%$ to $-20 \%$ from its annual average price.

***The CSR Strategy score, the Shareholders score and the Management score represent three of the 10 category scores whose combination, weighted proportionately based on the number of measures within each category, comprises the Thomson Reuters ESG Score, which is an overall company score based on the self-reported information in the environmental, social and corporate governance pillars (see * in this table). To calculate these 10 category scores, a percentile rank scoring methodology is adopted. As stated by Thomson Reuters "each category score is the equally weighted sum of all relevant indicators for each industry used to create it. The normalized weights are calculated excluding quantitative indicators with no data available in the public domain, as it would be highly inaccurate to assign a default value". For more details on category scores calculation, see Thomson Reuters (2019). 


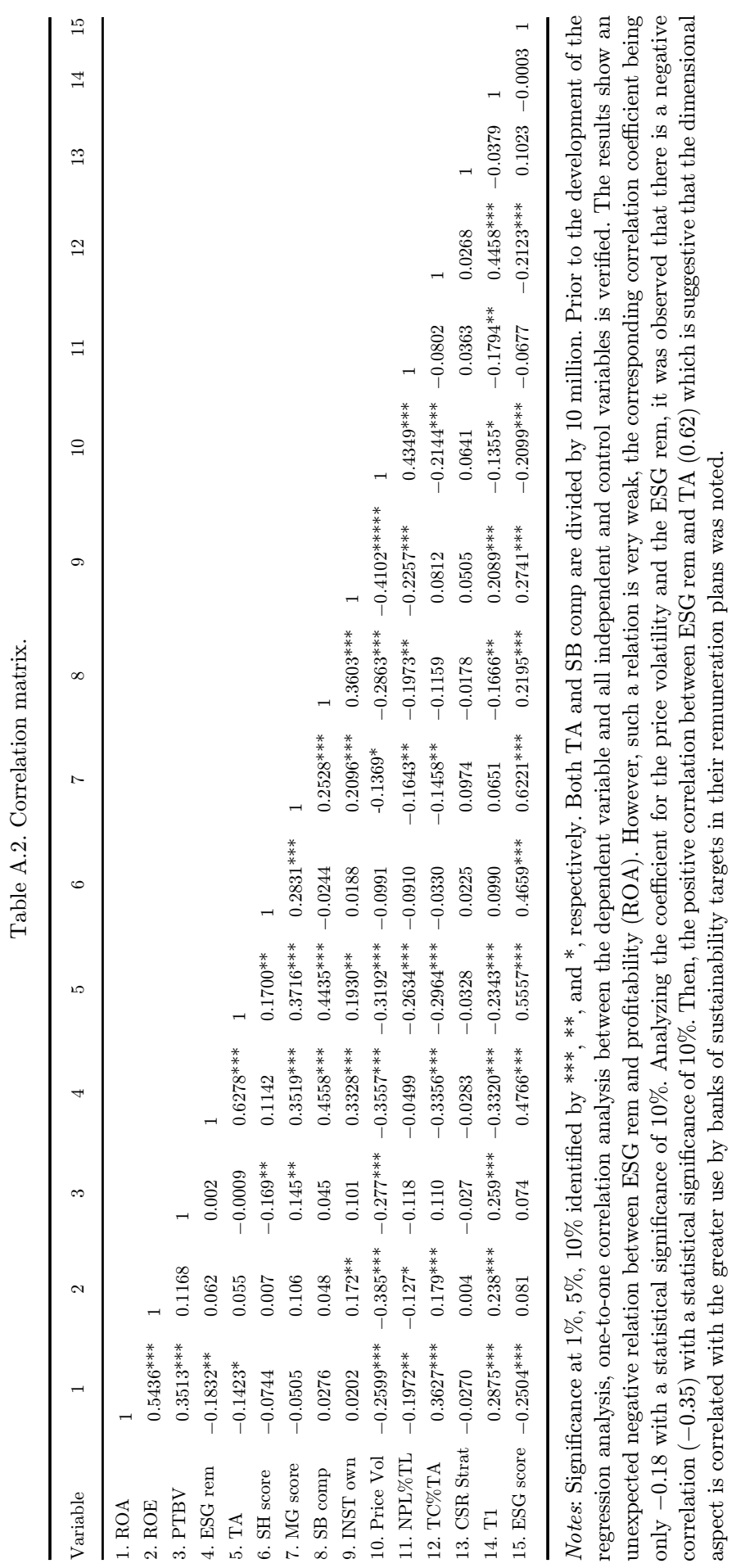




\section{References}

H. Abdelmotaal \& M. Abdel-Kader (2016) The use of sustainability incentives in executive remuneration contracts: Firm characteristics and impact on the shareholders' returns, Journal of Applied Accounting Research 17, 311-330.

R. D. Banker, G. Potter \& D. Srinivasan (2000) An empirical investigation of an incentive plan that includes nonfinancial performance measures, Accounting Review 75, 65-92.

R. Barontini, S. Bozzi, G. Ferrarini \& M. C. Ungureanu (2013) Directors' remuneration before and after the crisis: Measuring the impact of reforms in Europe, In M. Belcredi \& G. Ferrarini, (Eds.), Boards and Shareholders in European Listed Companies: Facts, Context and Post-Crisis Reforms (International Corporate Law and Financial Market Regulation, pp. 251-314). Cambridge: Cambridge University Press. doi: 10.1017/ CBO9781139629126.006.

BCBS - Basel Committee on Banking Supervision (2010) Compensation Principles and Standards Assessment Methodology, January.

BCBS - Basel Committee on Banking Supervision (2011) Range of Methodologies for Risk and Performance Alignment of Remuneration. May.

BCBS - Basel Committee on Banking Supervision (2015) Guidelines corporate governance principles for banks. July.

L. A. Bebchuk, A. Cohen \& H. Spamann (2010) The wages of failure: Executive compensation at Bear Stearns and Lehman 2000-2008, Finance Working Paper, No. 287/2010 ECGI. June.

A. Beltratti (2005) The complementarity between corporate governance and corporate social responsibiliy, The international association for the study of insurance economics, The Geneva Papers 30, 373-386.

P. Berrone \& L. R. Gomez-Mejia (2009) Environmental performance and executive compensation: An integrated agency-institutional perspective, Academy of Management Journal 52, 103-126.

M. Bianchi, A. Ciavarella, V. Novembre \& R. Signoretti (2011) Comply or explain: Investor protection through the Italian corporate governance code, Journal of Applied Corporate Finance 23, 107-121.

G. Birindelli, S. Dell'Atti, A. P. Iannuzzi \& M. Savioli (2018) Composition and activity of the board of directors: Impact on ESG performance in the banking system, Sustainability 10, 4699, doi: 10.3390/su10124699.

M. Brogi \& V. Lagasio (2018) Environmental, social, and governance and company profitability: Are financial intermediaries different? Corporate Social Responsibility Environmental Management, 1-12, doi: 10.1002/csr.1704.

S. J. Callan \& J. M. Thomas (2014) Relating CEO compensation to social performance and financial performance: Does the measure of compensation matter, Corporate Social Responsibility and Environmental Management 21, 202-227.

V. Cerasi \& T. Oliviero (2015) CEO compensation, regulation, and risk in banks: Theory and evidence from the financial crisis, International Journal of Central Banking 11, 241-297.

V. Cerasi, S. M. Deininger, L. Gambacorta \& T. Oliviero (2017) How post-crisis regulation has affected bank CEO compensation. BIS Working Papers, No. 630 April.

B. Cheng, I. Ioannou \& G. Serafeim (2013) Corporate social responsibility and access to finance, Strategic Management Journal 35 (1), 1-23.

C. S. A. Cheng, D. Collins \& H. Huang (2006) Shareholder rights, financial disclosure and the cost of equity capital, Review of Quantitative Finance and Accounting 27, 175-204.

I. A. Cheng, H. Hong \& J. A. Scheinkman (2015) Yesterday's heroes: Compensation and risk at financial firms, The Journal of Finance 70, 839-879. 
H. L. Chih, H. H. Chih \& T. Y. Chen (2010) On the determinants of corporate social responsibility: International evidence on the financial industry, Journal of Business Ethics 93 (1), 115-135.

J. Cordeiro \& J. Sarkis (2008) Does explicit contracting effectively link CEO compensation to environmental performance? Business Strategy and the Environment 17, 304-317.

J. R. Deckop, K. K. Merriman \& S. Gupta (2006) The effects of CEO pay structure on corporate social performance, Journal of Management 32, 329-342.

B. Díaz, R. García-Ramos \& M. García Olalla (2017) Does regulating remuneration affect the market value of European Union banks? Large versus small/medium sized banks, Regulation \& Governance, doi: 10.1111/rego.12175.

EBA (2015) Guidelines on sound remuneration policies under Articles 74(3) and 75(2) of Directive 2013/36/EU and disclosures under Article 450 of Regulation (EU) No 575/ 2013. 21 December. https://eba.europa.eu/documents/10180/1314839/EBA-GL-2015$22+$ Guidelines+on+Sound+Remuneration+Policies_EN.pdf/5057ed7d-8bf1-41b4ad74-70474d6c3158

R. G. Eccles, I. Ioannou \& G. Serafeim (2014) The impact of corporate sustainability on organizational processes and performance, Management Science 60(11), 2835-2857.

D. H. Erkens, M. Hung \& P. Matos (2012) Corporate governance in the 2007-2008 financial crisis: Evidence from financial institutions worldwide, Journal of Corporate Finance 18 (2), 389-411.

P. Esteban-Sanchez, M. de la Cuesta-Gonzalez \& J. D. Paredes-Gazquez (2017) Corporate social performance and its relation with corporate financial performance: International evidence in the banking industry, Journal of Cleaner Production 162, 1102-1110.

European Commission (2009) Commission Recommendation of 30 April 2009 complementing Recommendations 2004/913/EC and 2005/162/EC as regards the regime for the remuneration of directors of listed companies. 2009/385/EC. https://eur-lex.europa.eu/ legal-content/GA/TXT/?uri=CELEX:32009H0385

European Commission (2013) Directive 2013/36/EU of The European Parliament and of The Council of 26 June 2013, on access to the activity of credit institutions and the prudential supervision of credit institutions and investment firms. https://eur-lex.europa. $\mathrm{eu} /$ legal-content/EN/TXT/?uri=celex\%3A32013L0036.

Eurosif (2010) Remuneration. Available at http://www.eurosif.org/research/themereports/ remuneration. Accessed on February 2012.

R. Fahlenbrach \& R. M. Stulz (2010) Bank CEO Incentives and credit crisis, Fisher College of Business, SSRN Working Paper 2009-03-013. August.

C. M. Faller \& D. Zu Knyphausen-Aufseß (2018) Does equity ownership matter for corporate social responsibility? A literature review of theories and recent empirical findings, Journal Business Ethics 150, 15-40.

G. Ferrarini (2017) Regulating bankers' pay: Systemic risk, proportionality and culture, In: Bankers' Pay, Incentives and Regulation Conference. September, Lisbon. https://www. bportugal.pt/sites/default/files/bankers_pay_incentives_and_regulation_conference_ summary.pdf

G. Ferrarini \& M. C. Ungureanu (2011) Economics, politics, and the international principles for sound compensation practices: An analysis of executive pay at European banks, Vanderbilt Law Review 62 (2), 439-441; ECGI — Law Working Paper No. 169/2010. March.

C. Flammer, B. Hong \& D. Minor (2016) Corporate governance and the rise of integrating corporate social responsibility criteria in executive compensation: Antecedents and outcomes. Available at SSRN: https://ssrn.com/abstract=2831694 or http://dx.doi. $\operatorname{org} / 10.2139 /$ ssrn. 2831694 . 
F. J. Forcadell \& E. Aracil (2017) European banks' reputation for corporate social responsibility, Corporate Social Responsibility and Environmental Management, 24, 1-14.

M. B. Frye, E. Nelling \& E. Webb (2006) Executive compensation in socially responsible firms, Corporate Governance 14, 446-455.

FSB - Financial Stability Board (2009) FSB Principles for Sound Compensation Practices. Implementation Standards. 25 September 2009.

FSB - Financial Stability Board (2010) Thematic Review on Compensation: Peer Review Report 10-11. Available at http://www.financialstabilityboard.org/publications/ r_100330a.pdf.

FSB - Financial Stability Board (2013) Implementing the FSB Principles for Sound Compensation Practices and their Implementation Standards, Progress Report, 13 June 2012; Second Progress Report. 26 August.

FSB - Financial Stability Board (2015) Implementing the FSB Principles for Sound Compensation Practices and their Implementation Standards. Fourth Progress Report. November.

FSB - Financial Stability Board (2017a) Reducing misconduct risks in the financial sector. Progress Report to G20 Leaders. 28 June.

FSB - Financial Stability Board (2017b) Supplementary Guidance to the FSB Principles and Standards on Sound Compensation Practices. Consultative Document. June.

FSB - Financial Stability Board (2018) Supplementary Guidance to the FSB Principles and Standards on Sound Compensation Practices. The use of compensation tools to address misconduct risk. 9 March.

J. Galbreath (2011) Are there gender-related influences on corporate sustainability? A study of women on boards of directors, Journal of Management $\&$ Organization 17, 17-38.

A. Garel \& A. P. Romec (2017) Bank capital in the crisis: It's not just how much you have but who provides it, Journal of Banking and Finance 75, 152-166.

A. B. Goktan (2014) Impact of green management on CEO compensation: Interplay of the agency theory and institutional theory perspectives, Journal of Business Economics and Management 15, 96-110.

P. Gompers, J. Ishii \& A. Metrick (2003) Corporate governance and equity prices, Quarterly Journal of Economics 118, 107-155.

H. R. HassabElnaby, E. Mohammad \& A. A. Said (2010) Nonfinancial performance measures and earnings management, Advances in Management Accounting 18, 55-79.

H. R. HassabElnaby, A. A. Said \& B. Wier (2005) The retention of nonfinancial performance measures in compensation contracts, Journal of Management Accounting Research 17, $23-42$.

HLEG - High-Level Group on Sustainable Finance (2018). Financing a sustainable european economy. Final Report. Resource document. European Commission, https://ec.europa. eu/info/sites/info/files/180131-sustainable-finance-final-report_en.pdf. Accessed on 12 March 2018.

B. Hong, Z. F. Li \& D. B. Minor (2016) Corporate governance and executive compensation for corporate social responsibility, Journal of Business Ethics 136, 199-213.

B. Hong, Z. F. Li \& D. B. Minor (2015) Corporate governance and executive compensation for corporate social responsibility, Harvard Business School Working Paper No. 16-014. August.

HSBC (2017) Annual Report and Accounts. https://www.hsbc.com.

H. Huang, Q. Wang \& X. Zhang (2009) The effect of CEO ownership and shareholder rights on cost of equity capital, Corporate Governance 9, 255-270. 
H. H. Huang, M. L. Chan, I. H. Huang \& C. H Chang (2011), Stock price volatility and overreaction in a political crisis: The effects of corporate governance and performance, Pacific-Basin Finance Journal 19, 1-20.

A. P. Iannuzzi (2013) Le Politiche di Remunerazione Nelle Banche Tra Regolamentazione e Best Practices. Napoli: Edizioni Scientifiche Italiane.

S. Ibrahim \& C. C. Lloyd (2011) The association between non-financial performance measures in executive compensation contracts and earnings management, Journal of Accounting and Public Policy 30 (3), 256-274.

C. D. Ittner \& D. F. Larcker (1998) Are nonfinancial measures leading indicators of financial performance? An analysis of customer satisfaction, Journal of Accounting Research, 36, $1-35$.

C. D. Ittner, D. F. Larcker \& M. V. Rajan (1997) The choice of performance measures in annual bonus contracts, Accounting Review 72, 231-255.

C. D. Ittner, D. F. Larcker \& T. Randall (2003) Performance implications of strategic performance measurement in financial services firms, Accounting, Organizations and Society 28, 715-741.

Y. Y. Ji (2015) Top management team pay structure and corporate social performance, Journal of General Management 40, 3-20.

M. Karl (2015) Are ethical and social banks less risky? Discussion Papers, DIW Berlin.

J.-B. Kim, Y. Li \& L. Zhang (2011) CFOs versus CEOs: Equity incentives and crashes, Journal of Financial Economics 101, 713-730.

A. Kolk \& P. Perego (2014) Sustainable bonuses: Sign of corporate responsibility or window dressing? Journal of Business Ethics 119, 1-15.

K. A. Krippendorf (2004) Content Analysis: An Introduction to its Methodology, second edition. Thousand Oaks, CA: Sage.

R. La Porta, F. Lopez-de-Silanes, A. Shleifer \& R. Vishny (1998) Law and Finance, Journal of Political Economy 106, 6, 1113-1155.

Y. G. Lee, M. S. Park \& Y. Z. Shin (2017) The use of non-financial performance measures in CEO compensation contracts and stock price crash risk. Academic Seminar, 8, December, KAIST College of Business, https://www.business.kaist.ac.kr/_prog/seminar/ index.php?site_dvs_cd=en\&menu_dvs_cd $=070202 \&$ func_dvs_cd $=$ seminar\&year $=2017 \&$ mode $=$ V\&mng_no $=7835$.

I. Levina (2014) Remuneration in banking: Two lessons from history and current policy, political economy research institute. Working Paper Series Number 359. September.

K. Maas \& S. Rosendaal (2016) Sustainability targets in executive remuneration targets, time frame, country and sector, Business Strategy and the Environment 25, 390-401.

K. Maas (2018) Do corporate social performance targets in executive compensation contribute to corporate social performance? Journal of Business Ethics 148, 573-585.

L. S. Mahoney \& L. Thorne (2006) An examination of the structure of executive compensation and corporate social responsibility: A Canadian investigation, Journal of Business Ethics 69, 149-162.

C. Mallin \& A. Melis (2012) Shareholder rights, shareholder voting, and corporate performance, Journal of Management \& Governance 16, 171-176.

M. Russo \& N. Harrison (2005) Organizational design and environmental performance: Clues from the electronics industry, Academy of Management Journal 48, 582-593.

A. A. Said, H. R. HassabElnaby \& B. Wier (2003) An empirical investigation of the performance consequences of nonfinancial measures, Journal of Management Accounting Research 15, 193-223.

W. G. Simpson \& T. Kohers (2002) The link between corporate social and financial performance: Evidence from the banking industry, Journal of Business Ethics 35, 97-109. 


\section{E. D'Apolito et al.}

L. N. Switzer, Q. Tu \& J. Wang (2018) Corporate governance and default risk in financial firms over the post-financial crisis period: International evidence, Journal of International Financial Markets, Institutions $\&$ Money 52, 196-210.

Thomson Reuters (2019) Thomson Reuters ESG Scores. February. https://www.refinitiv. com/content/dam/marketing/en_us/documents/methodology/esg-scores-methodology.pdf

P. Velte (2016) Sustainable management compensation and ESG performance - the German case, Problems and Perspectives in Management 14, 17-24, doi: 10.21511/ppm.14 (4).2016.02.

M. W. Wu \& C. H. Shen (2013) Corporate social responsibility in the banking industry: Motives and financial performance, Journal of Banking \& Finance 37, 3529-3547. 